\title{
EFFECT OF DIFFERENT ADDITIVES ON THE SILAGE QUALITY OF SWEET POTATO BRANCHES ${ }^{1}$
}

\author{
NERMY RIBEIRO VALADARES ${ }^{2}$, VALTER CARVALHO DE ANDRADE JUNIOR ${ }^{3}$, ROSANA CRISTINA \\ PEREIRA $^{4}$, CÍNTIA MARIA TEIXEIRA FIALHO ${ }^{*}$, MARCOS AURÉLIO MIRANDA FERREIRA ${ }^{6}$
}

\begin{abstract}
Sweet potato branches have potential use in animal feeding, even fresh or ensiled, and some additives may enhance their quality. This study aimed at assessing silage quality of sweet potato branches using different additives. We ensiled sweet potato branches without additive (control) and with the addition of $10 \%$ disintegrated corn with straw and corncob (DCSC), 10\% sugarcane bagasse from alembic, 10\% citrus pulp, and $10 \%$ coffee husk. Three samples of each plot were obtained after drying for measurements of dry matter, crude protein, neutral detergent fiber (NDF), acid detergent fiber (ADF), cellulose, hemicellulose, lignin, mineral matter, starch, soluble sugars, $\mathrm{pH}$, lactic acid bacteria population, gas, and effluent losses. Silage with DCSC, citrus pulp, and coffee rusk reached the highest dry matter contents. Moreover, citrus pulp silage had a high content of NDF. In contrast, DCSC silage showed the lowest content of ADF. Lignin was low in silage with DCSC, citrus pulp, and control (without additive). Suitable amounts of starch, crude protein, and lactic acid bacteria population were found in all treatments. Silage with DCSC achieved the best results for the assessed variables. Therefore, DCSC is the most suitable additive to improve silage quality of sweet potato branches.
\end{abstract}

Keywords: Animal feeding. Alternative forage. Ipomoea batatas. Dry matter.

\section{QUALIDADE DE SILAGEM DE RAMAS DE BATATA-DOCE COM DIFERENTES ADITIVOS}

RESUMO - As ramas de batata-doce apresentam potencial de utilização na alimentação animal, na forma fresca e de silagem, sendo que a utilização de aditivos pode contribuir para a melhoria da qualidade da silagem das ramas. Objetivou-se com este estudo avaliar a qualidade da silagem de ramas de batata-doce com diferentes aditivos. Os tratamentos utilizados para a confecção das silagens foram: ramas puras; ramas + 10\% de MDPS (milho desintegrado com palha e sabugo); ramas $+10 \%$ de bagaço de cana de alambique; ramas $+10 \%$ de polpa cítrica; ramas $+10 \%$ de casca de café. Foram determinadas amatéria seca, proteína bruta, fibra de detergente neutro (FDN), fibra de detergente ácido (FDA), celulose, hemicelulose, lignina, cinzas, amido, açucares solúvel, $\mathrm{pH}$, população de Bactérias do ácido láctico, perdas por gases e efluentes. As silagens de ramas + MDPS, ramas + polpa cítrica e ramas + casca de café apresentaram os maiores teores de matéria seca. $\mathrm{Na}$ silagem de ramas + polpa cítrica foi registrada alto teor de FDN. Já na silagem de ramas + MDPS obteve-se o menor teor de FDA. O teor de lignina foi baixo nas silagens das ramas + MDPS, ramas puras e ramas + polpa cítrica. Os teores de amido, PB e populações de BAL foram adequados para todas as silagens. A silagem contendo ramas + MDPS apresentou os melhores resultados para as características avaliadas, de forma que o aditivo utilizado nesta silagem é o mais recomendado para as condições experimentadas.

Palavras-chave: Alimentação animal. Forragem alternativa. Ipomoea batatas. Matéria seca.

\footnotetext{
${ }^{*}$ Corresponding author

${ }^{1}$ Received for publication in $05 / 16 / 2017$; accepted in 12/04/2018.

${ }^{2}$ Institute of Agricultural Sciences, Universidade Federal de Minas Gerais, Montes Claros, MG, Brazil; nermyrv@gmail.com - ORCID: 0000-0001-7854-8111.

${ }^{3}$ Department of Agriculture, Universidade Federal de Lavras, Lavras, MG, Brazil; valter.andrade@ufla.br - ORCD: 0000-0002-5010-7725.

${ }^{4}$ Department of Agriculture, Instituto Federal Fluminense, Bom Jesus do Itabapoana, RJ, Brazil; rosana.pereira@iff.edu.br - ORCID: 00000002-6161-3252.

${ }^{5}$ Department of Agronomy, Universidade Tecnológica Federal do Paraná, Santa Helena, PR, Brazil; cintiafialho@utfpr.edu.br - ORCID: 0000-0002-1764-3921.

${ }^{6}$ Department of Agronomy, Universidade Federal dos Vales do Jequitinhonha e Mucuri, Diamantina, MG, Brazil; marcosmamf23@yahoo.com.br - ORCID: 0000-0002-9374-8127.
} 


\section{INTRODUCTION}

Sweet potato (Ipomoea batatas (L.) Lam.) is a tuber originally from Central and South Americas. It is a vegetable grown in all Brazilian regions and considered a rustic crop, with high resistance to pests and ability to grow on poor and degraded soils (PEREIRA JUNIOR et al., 2008). This tuber is mainly cultivated by family farmers in low-input use systems. It has been largely used in human and animal nutrition, as well as raw material for food, textile, paper, cosmetics, adhesive preparation, and carburant alcohol industries Andrade Júnior et al. (2009). The potential to produce large quantities of food at low costs and in a sustainable manner, together with its diversity of uses, makes this species particularly interesting as an option for family farming in all regions of the country (MONTEIRO, 2007). According to Silva (2001), when compared to corn and sorghum, sweet potato is more efficient regarding net energy per area and time units. This is due to its ability to grow a large root volume within a short cycle, at low cost throughout the year.

Fodder availability for grazing animals is uneven throughout the seasons as a consequence of climatic factors, with forage deficit in the summerwinter transition (FONTANELI et al., 2009). Added to this variation in forage availability, the need to use lower-cost feed options for ruminants contributes to increasing the demand for new alternatives (ÁVILA, et al., 2006). Given that the cost of food is one of the main impediments for small producers.

Branches of sweet potato can be used in animal feed, mainly for dairy cattle, either fresh or as silage materials (MONTEIRO, 2007). Moreover, this plant part is responsible for yields above $30.0 \mathrm{t} \mathrm{ha}^{-1}$ after 180 days of planting (VIANA et al., 2011; DORNAS, 2012). The ensiling of crop residues has the advantage of a low acquisition cost of material to be ensiled. The use of additives mixed with the branches is an alternative to increase silage nutritive value (MACEDO et al., 2015). Thus, we aimed to assess the quality of silages produced from sweet potato branches with different additives.

\section{MATERIAL AND METHODS}

The experiment was carried out in the JK university campus, "Universidade Federal dos Vales do Jequitinhonha e Mucuri - UFVJM", in Diamantina - Minas Gerais state, Brazil. The campus is located at an altitude of $1,400 \mathrm{~m}$, within the geographical coordinates of $18^{\circ} 9^{\prime} \mathrm{S}$ and $43^{\circ} 21^{\prime} \mathrm{W}$.

We chose the sweet potato genotype UFVJM13 from the plant-breeding program developed of the UFVJM. For seedling production, branch cuttings were removed from the germplasm bank collection with four to eight nodes, distributed into 72-cell polystyrene trays filled with Plantmax ${ }^{\circledR}$ (commercial substrate for vegetables), and then kept in a greenhouse under $50 \%$ shading.

The used soil had the following characteristics: $\mathrm{pH}=5.3, \mathrm{P}=1.3 \mathrm{mg} \mathrm{dm}^{-3}, \mathrm{~K}=17.7$ $\mathrm{mg} \mathrm{dm}{ }^{-3}, \mathrm{Ca}=0.2 \mathrm{cmol}^{-} \mathrm{dm}^{-3}, \mathrm{Mg}=0.1 \mathrm{cmolc} \mathrm{dm}^{-3}$, $\mathrm{Al}=0.4 \mathrm{cmolc} \mathrm{dm}^{-3}$, organic matter $=1.2 \mathrm{dag} \mathrm{kg}^{-1}$, $(\mathrm{V})=5.1 \%$, and potential CTC $(\mathrm{T})=7.7 \mathrm{cmolc} \mathrm{dm}^{-3}$. Prior to planting, we performed soil liming, as well as planting and topdressing fertilizations, according to the previous soil analysis and following the recommendations of Alvarez (1999). Irrigation was performed through a sprinkling system, according to crop water requirements.

Afterward, planting was carried out on March 7, 2013. Plots were designed with lines spaced 0.90 $\mathrm{m}$ apart and $0.30 \mathrm{~m}$ between plants, covering an acreage of about $1,000 \mathrm{~m}^{2}(20 \mathrm{~m} \times 50 \mathrm{~m})$ for branches and roots harvesting.

At 150 days after planting, plant shoots were harvested by cutting at soil level, and fresh weight was recorded (branches + leaves). Then, branches were chopped into about $2-\mathrm{cm}$ lengths using a forage grinder and then used to compose silages.

The silages were composed following a totally randomized design with five treatments: branches without additives - pure branches (control), branches $+10 \%$ disintegrated corn with straw and corncob (DCSC), branches $+10 \%$ sugarcane bagasse from alembic, branches $+10 \%$ citrus pulp, and branches $+10 \%$ coffee rusk, all in four replications.

After homogenization, we collected three samples of fresh forage from each plot for analysis before ensiling. One of the samples was frozen, another was immediately weighed and left to dry in a forced-air oven at $60{ }^{\circ} \mathrm{C}$ for 72 hours, and the remaining one was used for microbiological analysis.

We used the method described by Playne; McDonald (1981) to estimate buffer effect (BE) in forage samples. The dried samples were ground in a Wiley-mill and pass through a 1-mm sieve for determination of dry matter content (DM) and posterior analyses for contents of crude protein (CP), neutral detergent fiber (NDF), acid detergent fiber (ADF), cellulose (CEL), hemicellulose (HEM), lignin (LIG), pectin (PECT) mineral matter (MM), starch (St), and soluble sugars (SS), following the method described by Silva and Queiroz (2002). ADF and NDF contents were determined by the method proposed by Van Soest (1967) and described by Silva and Queiroz (2002).

The third sample was homogenized in a 225 $\mathrm{mL}$ sterile solution for 1 minute using a blender. Solution $\mathrm{pH}$ was readily recorded by a $\mathrm{pH}$ meter. Afterward, we filtered the mixture to obtain an aqueous extract. This extract was diluted successively and analyzed for lactic acid bacteria (LAB), enterobacteria, yeasts (YEA), and fungi, using selective culture mediums for each microbial group. LAB was quantified by plating on Rogosa 
Agar (Oxoid, Basingstoke, UK) and incubated at $32{ }^{\circ} \mathrm{C}$ for $48 \mathrm{~h}$, in a BOD incubator. The plates for enterobacteria were incubated at $36{ }^{\circ} \mathrm{C}$ for $18 \mathrm{~h}$. Yeasts and fungi were determined by plating on Malt Extract Agar (Oxoid) and incubated at $32{ }^{\circ} \mathrm{C}$ for $48 \mathrm{~h}$.

After sample removal for analysis, homogeneous chopped material was ensiled in PVC pipes with a Bunsen valve on the lids, which were sealed with adhesive tape. After 60 days, the seals were opened for removal of three new samples disregarding material at the ends of PVC pipes. Of these, one was weighed and then dried in a forced-air oven at $60{ }^{\circ} \mathrm{C}$, another was frozen, and the third was again used for $\mathrm{pH}$ and microbial analyses, which was made directly after PVC pipe opening.

Gas losses (GL) during ensiling were calculated by weighing PVC pipes at closing and opening and comparing to the mass of stored forage, without tare weight of PVC pipes (JOBIM et al., 2007). Effluent losses (EL) were estimated by the following equation: $\mathrm{E}=[100$ (Pab - Pen) $] /(\mathrm{MVfe})$; wherein: $E$ is the effluent production $\left(\mathrm{kg} \mathrm{Mg}^{-1}\right.$ green matter), $P a b$ is the mass $(\mathrm{kg})$ of PVC pipes at the opening, Pen is the mass $(\mathrm{kg})$ of PVC pipes at the ensiling time, $M V f e$ is the mass of green matter of forage silage $(\mathrm{kg})$.

The previously oven dried samples were ground in a Wiley-mill and passed through 1-mm sieve. Later, we determined DM, CP, NDF, ADF, CEL, HEM, LIG, St, and SS by the methods described by Silva and Queiroz (2002). All statistical analyses were performed by the Genes software and mean comparisons by the Tukey's test at $5 \%$ probability.

\section{RESULTS AND DISCUSSION}

The evaluated genotype reached a root average yield of $12.0 \mathrm{t} \mathrm{ha}^{-1}$, being slightly above the Brazilian average for $2010\left(11.8 \mathrm{t} \mathrm{ha}^{-1}\right)$ reported by IBGE (2012).

Before being ensiled, most of the assessed factors showed significant differences among samples by the F test, except for NDF, CP, and BE (Tables 1 and 3). For treatments with additives after ensiling, we observed significant results for all evaluated variables, except for EL (Tables 2 and 4).

When comparing control with silage added with DCSC before ensiling, we observed a variation in DM from $12.01 \%$ to $19.17 \%$ (Table 1). Table 2 shows that the greatest results for DM were found for treatments with DCSC $(21.9 \%)$, citrus pulp (21.7\%), and coffee rusk (21.4\%). The DM content for good quality silage should be within the range of 25 to $30 \%$ (FREITAS et al., 2006) to facilitate forage compression and air removal, avoiding butyric acid production as consequence of reduction in Clostridium proliferation, as well as soluble nutrient losses as a result of effluent formation (MAGALHÃES, 2013). In this study, the DM values found in silages with DCSC $(21.9 \%)$, citrus pulp $(21.7 \%)$, and coffee rusk $(21.4 \%)$ were near those obtained by Andrade Júnior et al. (2014) for the same genotype (about 19.4\%). Furthermore, the values found here are near the ideal minimum limit of $25 \%$.

Table 1. Mean values of the DM, NDF, ADF, CEL, HEM, LIG, MM, PECT, and CP for the five treatments of sweet potato branches before being ensiled.

\begin{tabular}{|c|c|c|c|c|c|c|c|c|c|}
\hline TREATMENT & DM & NDF & $\mathrm{ADF}$ & CEL & HEM & LIG & MM & PECT & $\mathrm{CP}$ \\
\hline & $\%$ & & & & $\% \mathrm{DM}$ & & & & \\
\hline $\begin{array}{l}\text { Pure branches } \\
\text { (control) }\end{array}$ & $\begin{array}{c}12.01 \\
b\end{array}$ & $\begin{array}{c}65.20 \\
\mathrm{a}\end{array}$ & $26.87 \mathrm{~b}$ & $14.73 \mathrm{~b}$ & $25.06 \mathrm{~b}$ & $11.97 \mathrm{a}$ & $19.35 \mathrm{a}$ & $13.27 \mathrm{a}$ & $\begin{array}{c}12.39 \\
\mathrm{a}\end{array}$ \\
\hline $\begin{array}{c}\text { Branches }+ \text { Citrus } \\
\text { pulp }\end{array}$ & $\begin{array}{c}18.12 \\
\mathrm{a}\end{array}$ & $\begin{array}{c}70.39 \\
\mathrm{a}\end{array}$ & $24.05 \mathrm{c}$ & $15.98 \mathrm{~b}$ & $\begin{array}{c}33.57 \\
\mathrm{ab}\end{array}$ & $8.90 \mathrm{~b}$ & $16.25 \mathrm{~b}$ & $12.52 \mathrm{ab}$ & $\begin{array}{c}12.08 \\
\mathrm{a}\end{array}$ \\
\hline $\begin{array}{c}\text { Branches }+ \text { Coffee } \\
\text { rusk }\end{array}$ & $\begin{array}{c}18.01 \\
\mathrm{a}\end{array}$ & $\begin{array}{c}68.38 \\
\mathrm{a}\end{array}$ & $29.12 \mathrm{a}$ & $18.14 \mathrm{a}$ & $24.67 \mathrm{~b}$ & $\begin{array}{c}10.82 \\
\mathrm{ab}\end{array}$ & $\begin{array}{c}15.29 \\
\mathrm{ab}\end{array}$ & $14.58 \mathrm{a}$ & $\begin{array}{c}11.90 \\
\mathrm{a}\end{array}$ \\
\hline $\begin{array}{c}\text { Branches }+ \\
\text { Sugarcane bagasse }\end{array}$ & $\begin{array}{c}13.64 \\
b\end{array}$ & $\begin{array}{c}62.46 \\
\mathrm{a}\end{array}$ & $30.98 \mathrm{a}$ & $\begin{array}{c}16.29 \\
\mathrm{ab}\end{array}$ & $23.06 \mathrm{~b}$ & $10.50 \mathrm{ab}$ & $16.52 \mathrm{~b}$ & $8.42 \mathrm{~b}$ & $\begin{array}{c}11.26 \\
\mathrm{a}\end{array}$ \\
\hline Branches+ DCSC & $\begin{array}{c}19.17 \\
\mathrm{a} \\
\end{array}$ & $\begin{array}{c}73.39 \\
\mathrm{a} \\
\end{array}$ & $20.07 \mathrm{~d}$ & $9.34 \mathrm{c}$ & $45.15 \mathrm{a}$ & $9.27 \mathrm{ab}$ & $13.50 \mathrm{c}$ & $8.16 \mathrm{~b}$ & $\begin{array}{c}11.20 \\
\mathrm{a}\end{array}$ \\
\hline VC (\%) & 6.34 & 12.71 & 24.45 & 6.57 & 15.2 & 13.61 & 7.85 & 11.23 & 6.53 \\
\hline
\end{tabular}

Means followed by a different lowercase letter in the column differ from each other at $5 \%$ probability by the Tukey's test. DM - Dry matter, NDF - Neutral Detergent Fiber, ADF - Acid Detergent Fiber, CEL Cellulose, HEM - Hemicellulose, LIG - Lignin, MM - mineral matter, PECT - Pectin, CP - Crude Protein. 
N. R. VALADARES et al.

Table 2. Values of the DM, NDF, ADF, CEL, HEM, LIG, MM, PECT, and CP for the five treatments of sweet potato branches after being ensiled (silage).

\begin{tabular}{cccccccccc}
\hline TREATMENT & DM & NDF & ADF & CEL & HEM & LIG & MM & PECT & CP \\
\hline & $\%$ & & & \multicolumn{7}{c}{$\begin{array}{c}\% \mathrm{DM} \\
\text { Pure branches } \\
\text { (control) }\end{array}$} & $15.13 \mathrm{~b}$ & $\begin{array}{c}64.69 \\
\mathrm{~b}\end{array}$ & $27.18 \mathrm{~b}$ & $\begin{array}{c}17.72 \\
\mathrm{a}\end{array}$ & $\begin{array}{c}28.12 \\
\mathrm{~b}\end{array}$ & $8.46 \mathrm{~b}$ & $18.80 \mathrm{a}$ & $9.39 \mathrm{a}$ & $\begin{array}{c}12.75 \\
\mathrm{ab}\end{array}$ \\
$\begin{array}{c}\text { Branches + Citrus } \\
\text { pulp }\end{array}$ & $21.66 \mathrm{a}$ & $\begin{array}{c}70.99 \\
\mathrm{a}\end{array}$ & $23.91 \mathrm{c}$ & $\begin{array}{c}16.21 \\
\mathrm{a}\end{array}$ & $\begin{array}{c}36.20 \\
\mathrm{a}\end{array}$ & $8.79 \mathrm{~b}$ & $14.63 \mathrm{~b}$ & $10.88 \mathrm{a}$ & $9.97 \mathrm{~b}$ \\
$\begin{array}{c}\text { Branches + Coffee } \\
\text { rusk }\end{array}$ & $21.42 \mathrm{a}$ & $\begin{array}{c}60.43 \\
\mathrm{~b}\end{array}$ & $31.55 \mathrm{a}$ & $\begin{array}{c}18.34 \\
\mathrm{a}\end{array}$ & $\begin{array}{c}19.02 \\
\mathrm{c}\end{array}$ & $13.62 \mathrm{a}$ & $13.57 \mathrm{bc}$ & $9.86 \mathrm{a}$ & $13.84 \mathrm{a}$ \\
$\begin{array}{c}\text { Branches + } \\
\text { Sugarcane bagasse }\end{array}$ & $15.86 \mathrm{~b}$ & $\begin{array}{c}64.82 \\
\mathrm{~b}\end{array}$ & $28.25 \mathrm{~b}$ & $\begin{array}{c}15.86 \\
\mathrm{a}\end{array}$ & $\begin{array}{c}27.83 \\
\mathrm{~b}\end{array}$ & $10.98 \mathrm{ab}$ & $15.19 \mathrm{~b}$ & $8.85 \mathrm{a}$ & $\begin{array}{c}10.23 \\
\mathrm{ab}\end{array}$ \\
Branches+ DCSC & $21.86 \mathrm{a}$ & $\begin{array}{c}62.08 \\
\mathrm{~b}\end{array}$ & $19.95 \mathrm{~d}$ & $\begin{array}{c}9.53 \\
\mathrm{~b}\end{array}$ & $\begin{array}{c}36.76 \\
\mathrm{a}\end{array}$ & $8.42 \mathrm{~b}$ & $11.82 \mathrm{c}$ & $5.37 \mathrm{~b}$ & $\begin{array}{c}10.86 \\
\mathrm{ab}\end{array}$ \\
\hline VC (\%) & 7.23 & 3.68 & 5.12 & 12.79 & 12.38 & 12.31 & 7.73 & 14.55 & 5.08 \\
\hline
\end{tabular}

Means followed by a different lowercase letter in the column differ from each other at $5 \%$ probability by the Tukey test. DM - Dry matter, NDF - Neutral Detergent Fiber, ADF - Acid Detergent Fiber, CEL Cellulose, HEM - Hemicellulose, LIG - Lignin, MM - mineral matter, PECT - Pectin, CP - Crude Protein

It can be seen in Table 1 that there were no differences for NDF content before ensiling, with an average DM of $68 \%$. Among all treatments, that with branches + citrus pulp had the highest value (70.99 $\%$ NDF) (Table 2); apart from that, no significant differences were observed among the other silages for this factor. However, the NDF contents found in all treatments were higher than the minimum limit of $60 \%$, which was reported by Van Soest (1994) as responsible for slowing down digestibility. Moreover, forage consumption by animals may also be affected since a high proportion of fibrous fraction, which composes NDF, fills the space between rumen and reticulum (SIMON et al.,2009).

Forage ADF content alters digestive capacity in animals, i.e., the higher the $\mathrm{ADF}$, the lower the DM digestibility. Simon et al. (2009) established a maximum limit of $40 \%$ ADF that cause no digestibility reduction. According to Table 1, the highest ADF contents before ensiling were observed for branches with sugarcane bagasse and coffee rusk additions, which were respectively $30.98 \%$ and $29.12 \%$ of the DM. In Table 2, one can see that the ADF values ranged from 19.95 to $31.55 \%$ for silages of different treatments. Silage with coffee rusk had the highest value (31.55\% of the DM), followed by those with sugarcane bagasse and the control, which achieved contents of 28.55 and $27.18 \%$ of the DM, respectively. On the other hand, branches before ensiling and mixtures with DCSC had the lowest values for this characteristic, which were 20.07 and $19.95 \%$ of the DM, respectively (Tables 1 and 2 ). Therefore, as ADF contents in all silages were suitable to ensure digestibility, the used additives were proven feasible.

As regarded by Van Soest (1994), structural carbohydrates, such as CEL, HEM, and pectin, play an active role in the quality of forages to be ensiled since their concentration and nature in cell walls influence directly forage degradability. CEL represents the largest portion of ADF, while HEM integrates NDF (VAN SOEST; ROBERTSON; LEWIS, 1991; SILVA; QUEIROZ, 2002). We observed a lower content of CEL in treatments with DCSC and in branches before ensiling (9.34\% DM), which remained in silages $(9.53 \%$ DM). Low contents of lignified CEL are interesting since it is the main component of ADF (ANDRADE JÚNIOR et al., 2014) and, in terms of digestibility, the degree of lignification is crucial (VAN SOEST, 1994).

Regarding CEL content, treatments with DCSC before ensiling had the lowest contents (9.34\% of the DM), which were kept after ensiling (9.53\% of the DM) (Tables 1 and 2). Before being ensiled, branches + coffee rusk stood out for the highest CEL content; however, after ensiling, no differences were found among treatments, and CEL content averaged in $17 \%$ of the DM, except for branches + DCSC. Yet, HEM was favored by adding corn (DCSC) $(36.8 \%$ of the DM) and citrus pulp (36.2\% of the DM) but reduced when coffee rusk was added (19.0\% of the DM). HEM contents varied from $19.02 \%$ of the DM for silage with the addition of coffee rusk to $36.76 \%$ in branches with DCSC (Table 2).

Concerning LIG, Table 1 shows that pure branches (control) (11.97\%) had results superior to those using citrus pulp $(8.90 \%)$ before ensiling. After ensiling, the highest LIG content was achieved by branches with coffee rusk (13.62\% of the DM). The treatment with coffee rusk had the highest LIG content compared to those that also had high CEL content (18.34\% of the DM) but low HEM content $(19.02 \%)$. This fact enabled an NDF concentration near the maximum limit that reduces digestibility. In addition, Jung and Deetz (1993) reported that a high LIG content in cell walls restrict microbial activity, as it reduces forage degradation, and hence nutrient 
exploitation. In other words, lower LIG contents are preferable.

If compared to the control before being ensiled, MM content reduced when additives were used with sweet potato branches. Among the treatments, branches + DCSC had lower values in both conditions, $13.50 \%$ and $11.82 \%$ of the DM, respectively (Tables 1 and 2). As for pectin, the lowest contents were observed when adding DCSC to branches before ensiling ( $8.16 \%$ of the DM), and remaining after ensiling, that is silage $(5.37 \%$ of the DM) (Tables 1 and 2). In cell walls, this carbohydrate is poorly lignified, being then more digestible and better used nutritionally. Additives have also decreased MM in all treatments for both branches before ensiling and silages. According to Andrade Júnior et al. (2014), higher amounts of MM are requested, mainly when the concentrations of $\mathrm{P}$ and $\mathrm{Ca}$ in it are elevated. The same authors evaluated silage production, chemical-bromatological composition, and fermentation ability of wilted sweet potato branches and found an average amount of $9.2 \% \mathrm{MM}$ in DM for the same genotype.

$\mathrm{CP}$ contents in branches before ensiling showed no differences among the treatments (Table 1). The CP contents in silages of branches with coffee rusk (13.84\% of the DM) were statistically superior to those with citrus pulp $(9.97 \%$ of the DM) (Table 2). The CP contents encountered here ranged from 9.97 to $13.84 \%$, very close to those reported by Figueiredo et al. (2012) $(11.59 \% \mathrm{CP}$ in $\mathrm{DM})$; these authors evaluated silages of twelve genotypes of sweet potato branches. Magalhães (2013) highlighted the importance of suitable CP contents in silages, as lower contents decrease animal consumption due to lack of nitrogen substrate for rumen bacteria. In this sense, the contents of $\mathrm{CP}$ observed in this study satisfactorily met the minimum value for regular activity of ruminal bacteria (6 to $8 \% \mathrm{CP}$ in forage DM) (MERTENS, 1994), and were also higher than the minimum needed to ensure a good forage intake $(8 \%)$ (MINSON, 1971).

Before ensiling, when sugarcane bagasse and DCSC were added to the branches, St content increased by $70 \%$ and $65 \%$, respectively (Table 3 ). The same trend was shown after ensiling (silage), and treatments with additives achieved higher $\mathrm{St}$ contents compared to the control. DCSC addition showed a St content of $15.20 \%$ of the DM, which was considerably higher than that of control $(5.21 \%)$ (Table 4). Silage with DCSC presented a higher St content compared to the control; it was already expected since corn is characterized by its $\mathrm{St}$ contents above 15\% (SILVA, 2001). Such elevated content of St in this treatment comes from DCSC composition, in which $70 \%$ carbohydrates are in $\mathrm{St}$ form, either composed of glucose polymers or of straight or branched chains (SILVA, 2013).

Table 3. Starch contents (St), soluble sugars (SS), pH, BE, LAB, YEA, and fungi for the five treatments of sweet potato branches before being ensiled.

\begin{tabular}{cccccccc}
\hline & $\mathrm{St}$ & $\mathrm{SS}$ & $\mathrm{pH}$ & $\mathrm{BE}$ & LAB & YEA & Fungi \\
\cline { 2 - 8 } TREATMENT & \% DM & $\% \mathrm{DM}$ & - & & & $\log \mathrm{cfu} / \mathrm{g}$ & \\
\hline Pure branches (control) & $7.24 \mathrm{~b}$ & $6.34 \mathrm{~b}$ & $6.39 \mathrm{a}$ & $\begin{array}{c}6.58 \\
\mathrm{a}\end{array}$ & $5.95 \mathrm{c}$ & $4.59 \mathrm{~b}$ & $4.36 \mathrm{~b}$ \\
Branches + Citrus pulp & $12.94 \mathrm{ab}$ & $11.63 \mathrm{~b}$ & $6.33 \mathrm{a}$ & $\begin{array}{c}7.33 \\
\mathrm{a}\end{array}$ & $5.07 \mathrm{~d}$ & $5.79 \mathrm{a}$ & - \\
Branches + Coffee rusk & $7.44 \mathrm{~b}$ & $9.56 \mathrm{~b}$ & $6.43 \mathrm{a}$ & $\begin{array}{c}6.18 \\
\mathrm{a}\end{array}$ & $8.13 \mathrm{a}$ & $5.75 \mathrm{a}$ & $4.67 \mathrm{a}$ \\
$\begin{array}{c}\text { Branches + Sugarcane } \\
\text { bagasse }\end{array}$ & $19.95 \mathrm{a}$ & $12.56 \mathrm{a}$ & $6.41 \mathrm{a}$ & $\begin{array}{c}5.84 \\
\mathrm{a}\end{array}$ & $5.08 \mathrm{~d}$ & $5.78 \mathrm{a}$ & - \\
Branches+ DCSC & $17.29 \mathrm{a}$ & $10.91 \mathrm{~b}$ & $5.99 \mathrm{~b}$ & $\begin{array}{c}7.69 \\
\mathrm{a}\end{array}$ & $7.02 \mathrm{~b}$ & $4.22 \mathrm{c}$ & $4.61 \mathrm{ab}$ \\
\hline VC (\%) & 20.43 & 18.55 & 1.26 & 12.74 & 4.69 & 2.79 & 3.17 \\
\hline
\end{tabular}

Means followed by a different lowercase letter in the column differ from each other at $5 \%$ probability by the Tukey's test. BE - buffer effect

LAB - Lactic acid-producing bacteria. YEA - Yeasts.

The $\mathrm{pH}$ of treatments with DCSC was 5.99, being smaller than that of the other treatments, which averaged 6.39 (Table 3). As pointed in Table 4, silages had low $\mathrm{pH}$ values in general; nevertheless, citrus pulp and sugarcane bagasse additions did not meet the $\mathrm{pH}$ standards established by McDonald
(1981), who consider a range of 3.8 to 4.2 as adequate for fermentation completion. No differences were found between treatment with DCSC and the control regarding $\mathrm{pH}$, being equal to 3.9. In contrast, the one with coffee rusk had an intermediate $\mathrm{pH}$ value (3.8) (Table 4). 
Regarding SS, it is noteworthy to highlight the addition of sugarcane bagasse both before and after ensiling (Tables 3 and 4). In general, the contents of SS found in all treatments, except for citrus pulp, met recommendations by Ohmomo et al. (2002) for production of silage with high nutritional value, in which sugars must be over $2 \%$.

Table 4. Contents of starch (St), soluble sugars (SS), pH, LAB, GL, and EL found in the five treatments of sweet potato branches after being ensiled (silage).

\begin{tabular}{|c|c|c|c|c|c|c|}
\hline & St & SS & $\mathrm{pH}$ & $\mathrm{LAB}$ & GL & EL \\
\hline TREATMENT & $\begin{array}{c}\% \text { of the } \\
\text { DM }\end{array}$ & $\%$ of the DM & - & $\log \mathrm{cfu} / \mathrm{g}$ & $\% \mathrm{DM}$ & $\mathrm{kg} / \mathrm{t}$ silage \\
\hline $\begin{array}{l}\text { Pure Branches } \\
\text { (Control) }\end{array}$ & $5.21 \mathrm{c}$ & $2.19 \mathrm{~b}$ & $3.91 \mathrm{a}$ & $6.76 \mathrm{a}$ & $3.1 \mathrm{a}$ & $2.7 \mathrm{a}$ \\
\hline $\begin{array}{l}\text { Branches }+ \\
\text { Citrus Pulp }\end{array}$ & $10.91 \mathrm{ab}$ & $1.45 \mathrm{~b}$ & $3.74 \mathrm{c}$ & $5.05 \mathrm{~b}$ & $0.2 \mathrm{~b}$ & $1.7 \mathrm{a}$ \\
\hline $\begin{array}{l}\text { Branches }+ \\
\text { Coffee rusk }\end{array}$ & $7.89 \mathrm{bc}$ & $2.87 \mathrm{~b}$ & $3.81 \mathrm{~b}$ & $7.47 \mathrm{a}$ & $0.3 \mathrm{~b}$ & $1.5 \mathrm{a}$ \\
\hline $\begin{array}{c}\text { Branches + } \\
\text { Sugarcane } \\
\text { bagasse }\end{array}$ & $10.92 \mathrm{ab}$ & $6.15 \mathrm{a}$ & $3.61 \mathrm{~d}$ & $5.25 \mathrm{~b}$ & $2.9 \mathrm{a}$ & $3.3 \mathrm{a}$ \\
\hline $\begin{array}{l}\text { Branches+ } \\
\text { DCSC. }\end{array}$ & $15.20 \mathrm{a}$ & $3.11 \mathrm{~b}$ & $3.93 \mathrm{a}$ & $7.45 \mathrm{a}$ & $0.1 \mathrm{~b}$ & $2.0 \mathrm{a}$ \\
\hline $\mathrm{VC}(\%)$ & 20.57 & 24.37 & 0.89 & 7.18 & 28.01 & 47.43 \\
\hline
\end{tabular}

Means followed by a different lowercase letter in the column differ from each other at $5 \%$ probability by the Tukey test. LAB - Lactic acid-producing bacteria, GL- Gas losses, EL- Effluent losses.

The BE of a forage is its ability to withstand $\mathrm{pH}$ variations (McDONALD, 1981). Regarding this variable, our results were close to those found by Dornas (2012), who found an average of 5.70 for BD -23 genotype (UFVJM-13). Moreover, significant differences among treatments were found for $\mathrm{BE}$ (Table 3)

As displayed in Tables 3 and 4, LAB population were above the minimum required, varying from 5.07 to $8.13 \mathrm{log} \mathrm{cfu} / \mathrm{g}$ in branches before ensiling (Table 3 ) and 5.05 to $7.47 \mathrm{log} \mathrm{cfu} / \mathrm{g}$ in silages (Table 4). Silages with citrus pulp and sugarcane bagasse presented similar values, which were 5.1 and $5.3 \log \mathrm{cfu} / \mathrm{g}$, respectively. On the other hand, silages with coffee rusk and DCSC presented the same value for LAB population (7.5 log cfu/g), which did not differ statistically from the control. McDonald (1981) states that silage success depends on a suitable number of lactic acid bacteria in order to ensure an adequate lactic acid production. This is because lactic acid-producing bacteria are the main microorganisms acting in the fermentation process for silage conservation. According to Santos et al. (2011), the minimum value to maintain losses at lower levels during the process is $5 \log \mathrm{cfu} / \mathrm{g}$.

With regard to fungi and yeasts found in the branches prior to ensiling, we noticed that citrus pulp, coffee rusk, and sugarcane bagasse showed higher values for yeast compared with those in DCSC and the control. Treatments with citrus pulp and bagasse showed no fungi. Moreover, a larger population of fungi was found when coffee rusk was added to sweet potato branches (Table 3 ).

Table 4 shows that GL ranged from 0.1 to
$3.1 \%$. This might have occurred due to homofermentative bacteria growth (LAB population) above the bare minimum requirement of $5 \mathrm{log} \mathrm{cfu} / \mathrm{g}$ (SANTOS et al., 2011). Silages in the control and those with sugarcane bagasse showed the largest losses, being of $3.1 \%$ and $2.9 \%$, respectively, without statistical difference between them. Concerning EL, no statistical difference was found among treatments, with values ranging from 1.7 to $3.3 \mathrm{~kg} / \mathrm{t}$ of silage (Table 4). GL is related to fermentation type. Fermentation is performed by homofermentative bacteria (LAB), which convert glucose into lactate, and thus losses are lower (McDONALD; HENDERSON; HERSON, 1991). Losses in silages with coffee rusk $(0.3 \%$ of the DM) were inferior to those reported by Barcelos et al. (2013), who also analyzed coffee rusk as an additive to sugarcane silage, and found values between 3.16 and $8.19 \%$. Overall, our results regarding GL (Table 4) were lower than those found by Siqueira, Reis and Schockeniturrino (2007), who studied sugarcane silage with various additives (chemical and bacterial ones), and observed values from $9.6 \%$ to $19.9 \%$.

\section{CONCLUSION}

Additive additions to sweet potato branches at a rate of $10 \%$ fresh matter were able to improve silage quality for most of the evaluated variables. Therefore, these additives are the most suitable for producing silage with a good quality when using sweet potato branches. 


\section{ACKNOWLEDGMENTS}

The authors thank the National Council for Scientific and Technological Development (CNPq) and the Foundations for Supporting Research of Minas Gerais State (FAPEMIG) for granting scholarships and resources to support the project development. This study was financed in part by the Coordenação de Aperfeiçoamento de Pessoal de Nível Superior - Brasil (CAPES) - Finance Code $001 "$.

\section{REFERENCES}

ALVAREZ, V. H. et al. Interpretação dos resultados das análises de solo. In: RIBEIRO, A. C.; GUIMARÃES, P. T. G.; ALVAREZ, V. V. H. (Eds.). Recomendações para o uso de corretivos e fertilizantes em Minas Gerais: $5^{\mathbf{a}}$ Aproximação. Viçosa: Comissão de Fertilidade do Solo do Estado de Minas Gerais, 1999. v. 1, cap. 5, p. 87-92.

ÁVILA, C. L. S. et al. Water-soluble carbohydrate contents of tanzaniagrass ensiled with additives. Revista Brasileira de Zootecnia, v. 35, n. 3, p. 648654, 2006.

ANDRADE JÚNIOR, V. C. et al. Selection of sweet potato clones for the region Alto Vale do Jequitinhonha. Horticultura Brasileira, v. 27, n. 3, p. 389-393, 2009.

ANDRADE JÚNIOR, V. C. et al. Produção de silagem, composição bromatológica e capacidade fermentativa de ramas de batata-doce emurchecidas. Horticultura Brasileira, v. 32, n. 1, p. 91-97, 2014.

BARCELOS, A. F. et al. Características fermentativas de selagens de polpa de café com diferentes proporções de casca de café. Boletim da Indústria Animal, v. 70, n. 3, p. 206-214, 2013.

DORNAS, M. F. S. Seleção de genótipos de batatadoce para a produção de silagem de ramas. 2012. 51 f. Dissertação (Mestrado em Produção Vegetal) Universidade Federal dos Vales do Jequitinhonha e Mucuri, Diamantina, 2012.

FIGUEIREDO, J. A. et al. Avaliação de silagens de ramas de batata-doce. Horticultura Brasileira, v. 30, n. 4, p. 708-712, 2012.

FREITAS, A. W. P. et al. Avaliação da qualidade nutricional da silagem de cana-de-açúcar com aditivos microbianos e enriquecida com resíduo da colheita de soja. Revista Brasileira de Zootecnia, v. 35 , n. 1 , p. $38-47,2006$

FONTANELI, R. S. et al. Gramíneas forrageiras anuais de verão. In: FONTANELI, R. S.; SANTOS, H. P.; FONTANELI, R.S. (Eds.). Forrageiras para integração lavoura-pecuária floresta na região sul -brasileira. Passo Fundo: Embrapa Trigo, 2009. v. 1, cap. 7 , p. 231-240.

INSTITUTO BRASILEIRO DE GEOGRAFIA E ESTATÍSTICA - IBGE. Produção Agrícola Municipal: Culturas temporárias e permanentes, 2012. 39 p.

JOBIM, C. C. et al. Avanços metodológicos na avaliação da qualidade da forragem conservada. Revista Brasileira de Zootecnia, v. 36, sup., p. 101$119,2007$.

JUNG, H. C.; DEETZ, D. A. Cell wall lignification and degradability. In: JUNG, H. C.; BUXTON, D R.; HATFIELD, R. D. (Eds.). Forage cell Wall structure and digestibility. Madison: American Society of Agronomy, 1993. v. 1, cap. 4, p. 315-346.

MACEDO, F. B. et al. Additives in ensiling palisade grass managed under grazing intensities. Acta Scientiarum, v. 37, n. 4, p. 357-363, 2015.

MAGALHÃES, F. A. Valor Nutritivo das Silagens da Brachiaria Decumbens Colhidas em Três Idades. 2013. 135 f. Tese (Doutorado em Zootecnia). - Universidade Federal de Minas Gerais Escola de Veterinária, Belo Horizonte, 2013.

McDONALD, P. The biochemistry of silage. Chichester: John Wiley \& Sons, Madson, 1981. 218 p.

McDONALD, P.; HENDERSON, A. R.; HERSON, S. J. E. Biochemistry of silage. 2 ed. Marlow: Chalcombe Publications, 1991. 340 p.

MERTENS, D. R. Regulation of forage intake. In: FAHEY JR., G. C. (Ed.). Forage quality, evaluation, and utilization. Madison: American Society of Agronomy, 1994, v. 1, cap. 11, p. 450493

MINSON, D. J. The digestibility and voluntary intake of six varieties of Panicum. Australian Journal of Experimental Agriculture And Animal Husbandry, v. 11, n. 48, p. 18-25, 1971.

MONTEIRO, A. B. Silagens de cultivares e clones de batata doce para alimentação animal visando sustentabilidade da produção agrícola familiar. Revista Brasileira de Agroecologia, v. 2, n. 2, p. 978-981, 2007.

OHMOMO, S. et al. Silage and microbial performance, old history but new problem. JARQ, v. 36, n. 2 p. $59-71,2002$. 
PEREIRA JÚNIOR, L. R. et al. Parcelamento do esterco bovino na produção de batata-doce. Revista Verde, v. 3, n. 3, p. 12- 16, 2008.

PLAYNE, M. J.; McDONALD, P. The buffering constituents of herbage. Journal of Food Science and Agriculture, v. 17, n. 6, p. 264-268, 1981.

SANTOS, E. M. et al. Populações microbianas, perfil fermentativo e composição bromatológica de silagens de capim-braquiária em diferentes idades de rebrotação. Revista Brasileira de Zootecnia, v. 40, n. 4, p. 747-755, 2011.

SILVA, J. M. Embrapa Gado de Corte Divulga: Silagem de Forrageiras Tropicais. 2001. Disponível: $\quad<$ http://www.cnpgc.embrapa.br/ publicacoes/divulga/GCD51.html $>$. Acesso em: 06 nov. 2016.

SILVA, D. J.; QUEIROZ, A. C. Análise de alimentos: métodos químicos e biológicos. 3. ed. Viçosa: MG, 2002, 235 p.

SILVA, G. S. P. Concentração de amido e estimativa de rendimento de álcool em batatadoce cultivada com diferentes fontes e doses de potássio. 2013. 66 f. Dissertação (Mestrado em Bioenergia) - Universidade Estadual do Centro Oeste, Guarapuava, 2013.

SIMON, J. E. et al. Consumo e digestibilidade de silagem de sorgo como alternativa para alimentação suplementar de ruminantes na amazônia oriental. Amazônia: Ciência. \& Desenvolvimento, v. 4, n. 8, p. 103-119, 2009.

SIQUEIRA, G. R.; REIS, R. A.; SCHOCKENITURRINO, R. P. Perdas de silagens de cana-de-açúcar tratadas com aditivos químicos e bacterianos. Revista Brasileira de Zootecnia, v. 36, n. 6, p. 2000-2009, 2007.

VAN SOEST, P. J. Development of a comprehensive system of feed analysis and its application to forages. Journal of Animal Science, v. 26, n. 1, p. 119-128, 1967.

VAN SOEST, P. J.; ROBERTSON, J. B.; LEWIS, B. A. Methods for dietary fiber, neutral detergent fiber, and nonstarch polysaccharides in relation to animal nutrition. Journal of Dairy Science, v. 74, n. 10 , p. $3583-3597,1991$.

VAN SOEST, P. J. Nutritional ecology of the ruminant. 2. ed. Ithaca, NY: Cornell University Press, 1994, 476 p.
VIANA, D. J. S. et al. Potencial de silagens de ramas de batata-doce para alimentação animal. Ciência Rural, v. 41, n. 2, p. 1466-1471. 2011. 